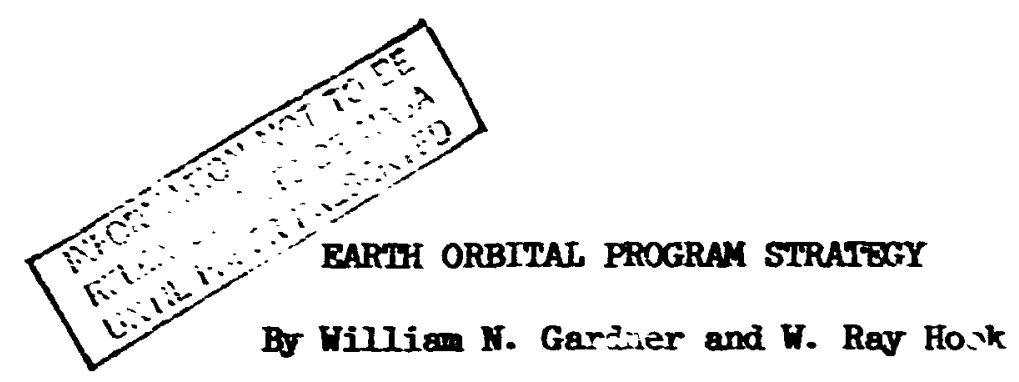

HASA iangley Research Center Langley Station, Hampton, Va.

Presentei at the 1968 SAE Space Technology Conference

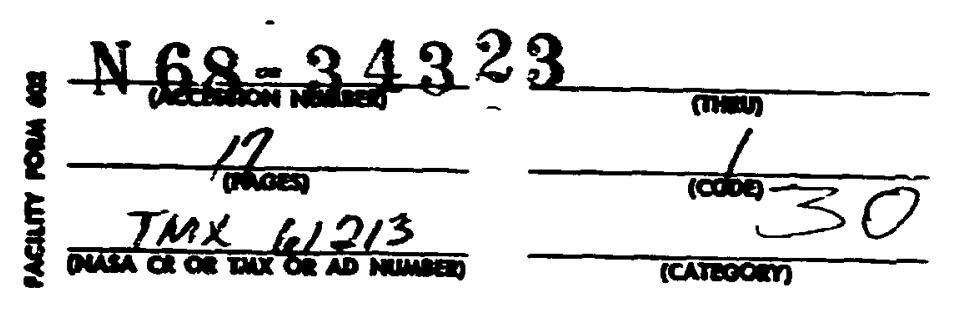

$$
\begin{aligned}
& \text { Washington, D.C. } \\
& \text { May 8-10, } 1968
\end{aligned}
$$

GPO PRICE

CSFII PRICE(S)

Hard copy $(\mathrm{HC}) \frac{3.00}{165}$
Microfiche (MF) 165

n 653 July 65 
ABSTRAC:

Through ar examination of NASA functions and space program areas and their interrelaticnship, it is shown that the objectives of NASA earth crbital programs are: to develop space systems that vill contribute to the solution of basic national problems by exploitirig space for himar welfare and knowledge, to exploit space for the advancerent of science and technology, and to develop space capabilities precursor to planetary exploration. The role of a space station in the earth orbital program is that of a manned orbital research facility capable of exploiting the unique festures of the space environment in combination with the sapabilities of man as an onbourd investigat or to accomplish a broad spectrum of research and development in all areas of interest. Kan's role in the orbiting research facility is similar to his role in a research laboratcry on earth. His ability is nhservs and act upcri unforeseen phenomens and events when coupled with the earth overview, the space environment, and the scientific instrumentation ana equipment which can be available aooard an orbiting laboratory offers a unique opportunity. A manned orbiting research facility, however, should nat be utilized to perform functions or programs which can be done economically and reliably by eutcmated spacecraft. 


\title{
EARTH ORBITAL PROGRAM STRATEGY
}

\author{
William N. Gardner and W. Ray Hook \\ MASA Langley Research Center \\ Langley Station, Hampton, Va.
}

THE SPACE ACT OF 1958 CHARGED the National Aeronautics and Space Administration with the responsibility to conduct research into problems of flight within and outside the earth's atmusphere; to develop, construct, test, and operate aeronautical and space vehrcles for research purposes; and to perform such other activities as may be required for the exploration of space. In fulfilling this respoinsibility, KASA earth orbital research activities have played a significant role through the utilization of both autcmated and manned satellites. Technological and operational capabilities have nor progressed to the point where it is feasible to develop, construct, test, and operate $a$ manned space station in earth orbit. In order to design properly and to utilize effectively such a spacecraft, it is mandatory that the role of a space station in the earth orbital program and the activities planned to be conducted aboard the station be well understood. The objective of this paper is to contribute to an understanding of the space-station role through a consideration of the functions of MASA in carrying out the nation's space program and through an effort to place the total earth orbital program in Jogical perspective. Additionally, some of the general features which an effective space station must include are defined.

\section{SPACE PROGRAM PERSPECTIVE}

A true understanding of the role of a space station in an earih orbital program can best be achieved by examining the tot 1 IASA space program in such a manner that earth orbital programs are placed in perspective. Ouce the total space program is in full perspective view, the potential contributions of a space station can be seen to influence all program areas. In order to achieve the perspective, it is necessary to review the functions of KASA in fulfilling the national space program objectives.

The national space progrem objectives were established within the Space Act of 1958, and the functions of NASA in fulfilling these objectives can be rather simply stated as follows: the exploration of space, the advancement

Gardner and Hook 
of sclence, and the prorlsion of services to the nation. The activities or program areas wich support each of these funciions are fairly straightforward for the first two functions. However, the service function is scomewhat more complex and is dependent on the capabilities developed as a part of the other functions. It is for these reasons that by far the greater share of MSA effort has been expended to date in support of space exploration and science. These functions, their supporting progran areas, and scme examples of the related activities are illustrated in Table $I$.

TABLE I - MASA FUNCTONS

w oxponarion of sence

\begin{tabular}{|c|c|}
\hline Procenam areas & MCTWHIES/PROKCTS \\
\hline unne & 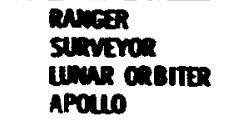 \\
\hline punctapy & $\operatorname{mans}$ \\
\hline cusctic & \multirow[t]{2}{*}{ ono } \\
\hline Asteomany & \\
\hline
\end{tabular}

Bolcration of Space - The exploration of space as 31lustrated in Table I(a) involves earth orbital, lunar, solar, planetary, galactic, and intergalactic programs. Althcugh the field of astronaw is generally classified as science, it represents $\operatorname{man}^{2} s$ first wode of space exploration and will continue to fuleill a significant role in space exploration for years to cone. The major activities of MASA to date have been concentrated in these program areas and lunar exploration has recelved by far the greatest support. Since the moon is our nearest celestial nelghbor, this support is very logical, but as our knowledge and understanding of the moon increases and as our technological capability grows, planetary exploration will receive increasing attention. This Breater emphasis on the planets wll ultimately lead to manned landings on the nearer planets. Feasibility studies of such missions have aiready been made and the technology requirements for such missions are well understood.

Scientific Advancement - Scientific advancement as IIlustrated in Table $I(b)$ includes supporting prograins in astrophysics, bioscience, physical science, earth science, and atmospheric science. Activities in these

Gardner and Hook 
TAQLE 1.- CONTHUEZ

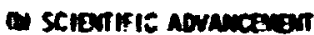

\begin{tabular}{|c|c|}
\hline procenam aces & activities/macets \\
\hline ASthominreAsthomrsics & 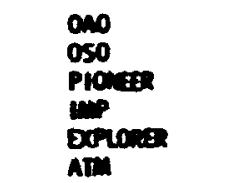 \\
\hline $\operatorname{sescran} x$ & cosameiut \\
\hline Prrsicul scraice & Dereon \\
\hline enchu scisax & oec \\
\hline anvosproic scienct & minus \\
\hline
\end{tabular}

areas inrolve coprehensive supporting research as well as space flight projects and these activities are aimed at achieving advancenents in our understanding of fundementel physical processes and lars. Interest and earth cobltal activity in these scientific areas wil: contime to grow as ow technological capability to utilize epace increases. Space conaitions such as velghtlessness, absence of atwosphere, and comprehensive orervieu of earth are unique research enfironents wich have nevar before been available to scientists. Absence of atwosphere offers an unparalleled opportunity for adrancenent of astronov, and welghtiessness pernits advances in bioscience which probably could be achieved in no other way. Continental lend asses and reather systens can only be viewed as an entity from space. A significant increase in capability to capitalize on the usefulness of space will be realized when it becones posisible to make greater utility of man in space as a scientist equipped wth the necessary instrunentation and support. Serrice - The MSA service function, Illustrated in Table $I(c)$, is one which has $y_{\text {-c }}$ to cone into full pronirence, but which offers great potential to the nation in terms of utilizing space for the benefit of bwan welfare. The service function has waw facets anci includes technologs developent programs for both space and aeronautics as vell as prograns in space operations and applications. Activities in these areas are rather broad, interworen, and comprehensive; they also serve national interests, including IASA purposes. The distinct identification of MSA parposes within national interests is sonewhat arbitrary and is intended to exphasize some of the varied aspects of the service function illustrated in the following materiul.

Gariner and Hook 
TABLE I - CONCLUDED

id SERvices

\begin{tabular}{|c|c|}
\hline PRLERN NRAS & ACTIVITIES/PROIECTS \\
\hline ADVANCSO ARROMUUTICS TECHNOLOCY & $\begin{array}{l}X-15 \\
M 2-F 2 \\
12-10\end{array}$ \\
\hline AONAMCED SPACE TECRIOLOCY & 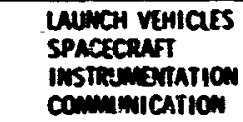 \\
\hline SPACE CPERATLOAS & $\begin{array}{l}\text { Lumor } \\
\text { macxinc } \\
\text { oulf processing } \\
\text { meralky } \\
\text { ceninI }\end{array}$ \\
\hline SPACE APPLICATLOAS AOD UTILIZATION & $\begin{array}{l}\text { TIROS } \\
\text { COMSAT } \\
\text { ESSA } \\
\text { ATS }\end{array}$ \\
\hline
\end{tabular}

Advanced space technology programs include a wide variety of activities necessary for the accomplishment of MAFA purposes and to berefit the nation. For example, the rather extensive technolog deve.opment activities in propalsion, space power, electronics, control, structures, materials, life support, and all spacecraft subsysto areas serve IMSA neeäs in terms of increasing our technological capability to accomplish exploratory and scientific space flight missions. This increasing technological capability, however. simultanecusly provides benefit to the nation in that it improres our ability to capitalize on the potential benefits to mankind of space utiliration. A necessary aijunct to the technological capability and mandatory for space utilization is, of course, the simultaneous development of space operational capability. The development of launch rehicles, launch operations techrilques, tracking and communications networks, and data handling systens and operations are all complex and necessary activities for the development of space operations capability. Probably the most sigmificant operational capability for both IASA needs and national benefit is the development of our capability to utilize man in space properly. The Mercury and Gemini act'vities were the first steps in this direction.

The contribution of space appiications and space utilization to the solution of today's problems is in an early stage of development. However, this activity appears to nffer enorwous benefits to the nation and to all mankind. SA activities in this aree. have been limited co technology utilization, the so-called technolos spin-of $t^{\circ}$, and to the communications and meteorological applications.

Gardner and jook 
This limitation has resulted from limitations in our technological and operational capability and not from lack of interest, the fact being that recognition of th s possible bencfits of space utilization places preater eriphasis and urgency on the reed i: develop tire nacessary technological and ofirational capability. Not only is it necess ry to develop spacecraft subsystem techróco and space flight operational casability, but also more important, it is necessary to develop the sensing instrumentation, data handling and interpretation techniques, and proper systems and methods for providing the ultimate user of information with information that is trilly useful to him. The systems and techniques required to provide useful information in fields such as agriculture, forestry, oceanography, hydrology, and mineral resources may or may not be very similar, and these application areas probably have requirements very different from those needed for applications such as communicatiors, meteorology, navigation, and traffic control. Nuch of the cevelopment activity needed to bring to fruition these application possibilities requires ground laboratory research, but a large part of the activity must also be accomplished in earth orbit. Barth orbit is the one single and certain space factor comon to all these application areas. The role of man in space to meet the needs of these applications in an ultimate operational status presents a nebulous question; however, it would seen at this time that automated spacecraft will ultimately satisfy most requirements. In the meantime, man in earth orbit properly equipped with research instrumentation can accelerate development of the space systems, operations, and techniques required to achieve the benefits which space utility offers.

One other service function which cannot be overlooked, even though it would seem not tog closely related to the subject of this paper, is the aeronautics technology program. Most of the activity in this program area is in support of national transportation reeds; honjever, it also includes supporting research on atmospheric entry, both earth and planetary, and spacecraft recovery. Considerable emphasis has been given to lifting-entry technoldgy leading to the ultimate development of econpmisal earth-orbit manred logistics operat1ons, for example, the MR-F2 and HL-10 lifting body flight projects. Economical logistic support is one of the key developments

Gardner and Hook 
required for effective utilization of man in orbit.

In sumary, the service function of NASA. is very broad in scope and involves servicing the needs of IIASA for space exploration and science well as servicing the need of the nation to utilize space for the benefit of home and hearth. The prime role of IASA in meeting the space utilization needs involves developing the tecinnical capability, proving the applicability, and furnishing the space operations necessary to support ultimate users.

After brief $2 y$ examining a full spectrum of RASA functions and program areas, it is seen that earth orbital activities comprise most of the IASA space flight missions and that the development of technology and space operations capability are the primary activ?ties in earth orbit.

\section{EARTH ORBITAL PFCGRAM}

Within the total space progract, those activities related to development of the capability to utilize space for human benefit are probably of greatest national interest. Msin's existence and well being re strongly influenced by the availability and use of earth rescurces and these resurces are being rapidly depleted both by growth in population and increase in individual demands. Adequate measurements of the quantitative and qualitative conditions that actually exist are fundamental to an understandirg of the problems and to effective efforts to alleviate them. The acquisition of such measurements requires suryeys of significant resources and conditions. Aircraft survey techniques have been ucilized very successfully but in limiced areas. There are critical needs for regular surveys in areas such as fresh water supplies and usage; land usage; soil and crop conditions; population trends; transportation status; marire life and wildlife distribution; fuel, ore, and mineral reserves; natural disaster survelliance; anc pollution and waste disposal. The advantages of the comprehensive overview and long flight duration available through utilization of spacecraft for such surveys offer greet potential to the nation for effective utilization of national resources. The meteorological satellite programs have already shown that surveys of global scope can be conducted on a routine basis with unexcelled csst effectiveness, and the utilization of communications satellites, as an example, has progressed

Gardner and Hook 
into the realm of commercial interest. All these factors demand that special emphasis be given to the development of applicable space technology and space operations techniques which are a part of the service functicin of NASA and which are earth orbital activities. The NASA science programs in atwospheric and earth science are inherently and intimately associated with the earth resources surveys just discussed. First, they also require earth orbital activity; second, most likely they require very similar orbital instrumentation and operations; aixd third, advancement of our knowledge of the earth and atmospheric sciences is inherent to the improvement of our understandinis and use of natural resources. Tatle II illustrates the comonality of survey instrumentation for earth resources, earth science, and atmosfheric science by listing the most coumon types. of sensors. It is not intended to imply that any siagle type sensor will meet all requirements for that sensor type, but it is intended to show a high degree of comonality in sensor technology. Similarly, there can be expected to be a high aegree of cownonality in dats format and handling requirerents. Furtharmore, the development of sensor technology and operational techniques for earth survey inherently increases our capability to perform mraningful spzce exploration. Sound knowledge and understanding of the earth, in the scient_fic sense, seem prerequisite to proper interpretation of planetary discoveries and to the understanding of planetology.

TABLE II.-

COMMONAUTY OF SURVEY INSTRUMENTATION FOR EARTH RESOUACES, EARTH SCIENCE, ARIO ATMOSPHERIC SCIENCE

\begin{tabular}{|c|c|c|c|}
\hline \multicolumn{2}{|c|}{ SERVICES } & SCIENCE & $\begin{array}{l}\text { Cominow } \\
\text { InSTrumanss }\end{array}$ \\
\hline $\begin{array}{l}\text { CULTURAL } \\
\text { RESOURCES }\end{array}$ & $\begin{array}{l}\text { MATUKAL } \\
\text { RESOURCES }\end{array}$ & $\begin{array}{l}\text { ATMOSPHERE AND } \\
\text { EARTH SCIEUCE }\end{array}$ & SEnsors \\
\hline $\begin{array}{l}\text { SOILS } \\
\text { CROPS } \\
\text { UND USE } \\
\text { POPUIATION TRENOS } \\
\text { TPANSPORTATION }\end{array}$ & $\begin{array}{l}\text { FRESH WAIER } \\
\text { FORESIRY } \\
\text { MARIIE LIFE } \\
\text { WILOLIFE } \\
\text { MIRERALS }\end{array}$ & $\begin{array}{l}\text { CARTOGRAPH } \\
\text { CEOOESY } \\
\text { GEOLOCY } \\
\text { GEOPHYSICS } \\
\text { OCEANOCRAPH } \\
\text { MEJEOROLOGY }\end{array}$ & $\begin{array}{l}\text { METRIC CAMERA } \\
\text { PANORAMIC CAMERA } \\
\text { TRACXING TEIESCOPE } \\
\text { SPECTRAL SCANER } \\
\text { RADIOUEIRR }\end{array}$ \\
\hline
\end{tabular}

Gardner and Hook

Earth orbit is not uniquely required for the astronomy, bioscience, or physical science progran areas, but absence of atmosphere, required. Earth orbit represents the most 
conven ent and economical means of meeting these requirements.

Most of the activity and accomplishment to date in these earth-orbital program areas has involved the use of automsica spacecraft systems. As has already been -ridicated, autcmated spacecraft may very adequately serve the operational reeds of the applications missions once the space applications caparility has been fully desionstrated, anä they may very well satisfy a significant por.tion of the science prugram area needs. However, the advantage of man in spase is found in his capability to observe and act ipon unforese $n$ phenomena and events and his capabilities have not yet heen fully applied. Research is inherently oriented to the discovery of the unknown and unanticipated an requires the active participation of a staff possessing the necessary judgment, experience, and sikills. Research and development, as has already besn discussea, will comprise the najor earth orbital activity for all program areas at least until such time as the technological and operational capabslity exists to capitalize materially on the usefulness of space for earth-related applications. The utilization of man in space permits experiments and tasks to be undertaken that would otherwise be inpossible or are so complex that the probability of successful completion with an autonatic system is low. For example, man's potential ability to erect and assemble large equipment in orbit and maintain it for long periods of time affords a flexibility and reliability that is beyond reasonable attainment for an automated syitem. The ability to conduct experiments and correlate inputs from ground-based specialists with results from many observatins and sensor neasurements affords an opp . . unity for an onboard scientific specialist to adapu experimental procedures to real time and possibly to edit and select the most aypropriate dita for transmission to the ground. Furthermore, automaied systems are constrained to perform those functions for which the technology either exists or can be developed with reasonable certainty and for which the tasks can be defined in complete detail and are not so complex or iniricate that the probability of successful completion is unattractive.

Man hours in space are inherent1* associated with high costs and it is therefore mandatory that every possible means be utilized to obtain maximum effectiveness cf man.

Garäner and Hook 
Systens, experiments, and instrumentation should not be designed in such a was that they raquire mar to periorm simple or routire tasiss wh ich can be eutumated and peshaps comanded from the ground. If the potentiels of man's imvolvenent ir. space activities are to be fully exploited, hovever, it is aecessary to proceed far bejond the Hercury and Gemini activities to develop the necessar; suppriting systems and operational techniques required. This development activity wist also be a significant eienent of the earth orbitai progran.

In swomary then, the earth orbital progran encoepasses: (1) the deve: ant of technology ard operational techniques $f$ - exrth resources survey, for other spece applications in addition is ccunications, for the utilization of space to conduct activities in all the science program areas, and for the effective utilication of man in space; ( 2 ! the conduct of the atrospheric and exrth science pionians; and (3) the conduct of the astroncy, bioscience, and plosical science progrens.

\section{TPE BOLE OF A SPACE STATIOA}

As has already been inplier the rolt of a space station in the earth-orbital progran is that of a nonned orbital research facility capable of exploiting the unique features of the space envirorment in conination with the cepabilities of man as onboard irvestigator to acco plish a iroad spectru of research and develcp nt. A space station can provide accelerat $3 \mathbf{i}$ developent of space sjstens that will contribute to the solv ion of basic national ard world probiess. It cen provide an unequaied opportunity for the studs of crucial scientific questions. It also can provide the required facility for dereloping adranced technology and operations procedure for proper utilization of nan in space systems and as a future explcrer of the near planets. These capabilities of a spece station then refresent the objectives for any space station program. It wast be noted, however, that a maned sface staticn should not be planned $i$ peifore runctions or execute programs that can be done better and nore eco.20nically ky automated satellites or by any other means. A manned space station utilized as a research laboratory can furnish the needed insight into the kind of neaningful reasurenents and observations that are required before autowated satellites can be employed to provide large amounts of data on a routine basis.

In the interin before a full capability space station becomes available, there obviously

Gardner and Hook 
will be considerable activity in all areas of interest utilizing autonated spacecreft to the limit of our capability. Similarly, the Apollo progran will provide valuable information relative to the provision of proper support for man in space and on methods for effectively utilizing man's skills. Advantage must be taken of evers opportunity to gain experience in and improve our capability for manned space operations.

\section{SPACE STATIOA BROAD REOUTREMETTS}

Crew Requirements - The crew requirements for a space station are necessarily as varjed and complex as the space experiment program itself. The crew size is a function of (1) the size of the spececraft laboratory, (2) the degree to wich the space station and the experiments are automated, (3) the frequency at wich crew members may be rotated from earth, (4) the size and the jisplinary content of the experiment program, and (5) the skill level required and degree of cross training achievable in the crew. Of these five factors, the degree of entomation of the experimental equipment and of station ranagement and maintenance has the greate.t effect on the crew size required by a given experiment program. Figure 1 shows that the effect of reducing the station-keeping task from 36 hours per day to 12 hours per dey increases the experimental man hours actually accomplished in a cumputer simulated space station mission. Both curves reach a maximun at 60 hours per day because the assumed experiments and the crew skills were optimam at that point.

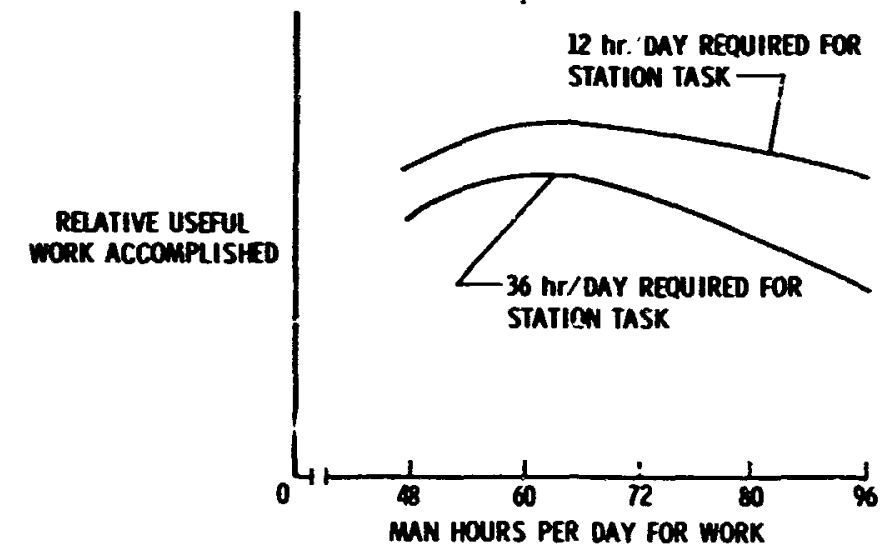

Gardner and Hook

Fig. I - Effect of station automation on man hours available for experiment work - six-man crew. 
sumerized in Table III. Those six skills for wich there is the greatest demand are indicated to be basic skills and may be required on a contimuous basis. It is recognized that these skills are also the basic skills required to operate the space station. The remaining skills mostly represent scientific specialties which are not necessarily required on a continuous basis and may be phased or shared in accordance with progrnm schedicing and demand.

TABLE III-SPACE-STATION STAFF REOUIREKENTS

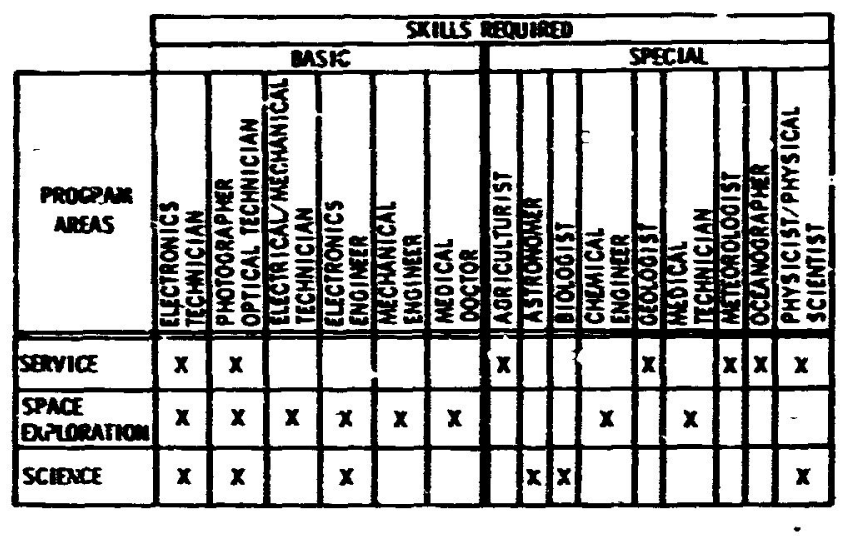

The technician skills are in greatest derana and these skills together with the engineering and medical skills plus two scientific skills would dictate a minimm station staff of eight men. The mmerous conflicting program requirements such as those cited previously would limit the maximm number of scientific specialists to about six men for effective utilization of staff time. These six wen together with the six men having basic skills and required contimously then indicate the maximin recessary single station staft might be ebout six to nine men.

It will be necessary in the interest of assuring a vell-coordinated and integrated station staff to train the specialists to perform certain other functions othe $i$ than their specialty, especially for energency operations.

Computer simulations of a 5-year space station mission indicate that for efficient scheduling of experimental tasks, the crew should be as versatile as practical, and that the experiments should be scheduled so as to reduce the numer of skills required during any given flight period in which the crew is fixed. For these simulations, the amount of the experimental program compieted varied as much as 25 percent, depending on the relative cross training of the crew.

Gardner and Hook

Performance Requirements - The most critical unknown relative to space station utilization is the requirement for, and the effectiveness of, 
artificial gravity. Table IV shows the tabilization and gravity requirements $c 1$ a balancej experiment program. It is Ecrer $1:-$ conceded that most of . he experiments $\epsilon$, ther require zero gravity ( jiology: fluids, brisvior, etc.) or s.re complicated by spacecraft rutetion (Astronomical pointing $0.1-0.01$ sec and earth resources 0.1 deg). Only those xperiments having to do with artificial gravity require it. The serious question remaining 's wether the crew requires artificial gravity pither from a physiological or a habitability point of view. In any event, the space station creu wust leurn to operate in a zero-gravity envizo. ment in order to carry out m-st of the crew thsks associated with the

I -earch and development programs.

TABE IT-SPACE-STATION PROGRM REOUHREMTS

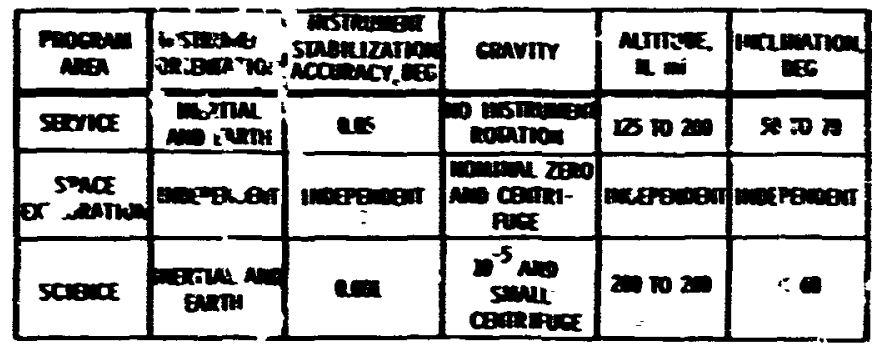

The attitude and stability and cortrul $C \vec{r}$ the space station are related to the gravity question and represent the area of most frequent space station performance requirements conflicts. Fox examle, the inighly stable inertial astrononical requirewent is in total conflict with the earth sleving recilirement for earth resources and netecrology. In either case, however, the pointing and stability requireaents are rigorous and suggest that the space-station attitude reference system and experiment sensor mounting and drive systens must be iinked with a strivture of suitable stiffness. The sensors that work together in the earth resources program should be mounted in a hangar arr a so that they may be boresighted and alined without incurring large extravehicular activity requirements. Figure 2 sumarizes the more significant space station necessary features. The space station design obviously must meei the requirements of the crew as well as the experiment program. The cabin will have a comfortabie shirt-sleeve environment which is as normal as practical, and a pressure commensurate vith crew denitrogenetion requirements before extravehicular act svity can be accomplished. The srew support equipment must

Gardner and Hook 
provide the crewman with adequate physical conditioning, recreation, rest, food, and personal hygiene without incumbering the rrewnan with tima-consuming and trivial tasks.

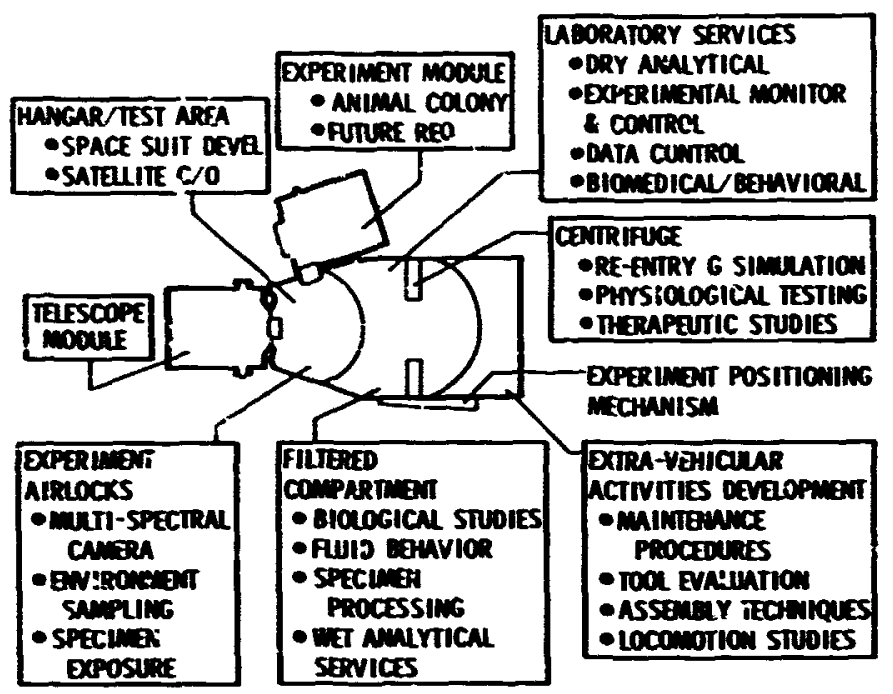

Fig. 2 - Space-staition features.

The spacecraft structure must provide ad .quate volume, thermal, metecroid and radiation protection for the crew and the experiment equir ment. It must also contain sufficient optical and vision windors, airlocks, and hatches to accounodate the experiment progran, logistic spacecraft docking, crew and cargo transfer, and nodular experiment concepts. The interior structure must accommodate the equipment and spacecraft subsysteus and provide a means for earth checkout and orbital maintenance. The power sustem should supply adequate continuous power without interfering with the experiment program pointing and vieiring requirenents. The data managenent and courmunications system must be flexible enough to accomnodate onboard displays, high data rates such as are associated with TV and radar, and at the same time respond to high data rate random erents such as a micrameteoroid velocity measurement.

Reliability studies indicate that a maintainable logistically supported sivation with a probability of mission success of 0.95 for a 1-year missici can be axpected to operate for a period of 5 years with 0.80 probability of sucGardner and Hook cess. Therefore, it is reasonable to assume that a 5-year experimental program could be profitably planned ror a single station.

The size of the space station is largely determined by the requirenents of the experiment program, but it is also a strong function of the 
T.aunch-vehicle capability and the requirement of the spare station to meet fut,ure requirements. A space station with a 260 -inch diameter sized to fit a Saturn IV-B stage is an eminently logical choice on this basis becausè it can be launcined into low-altitude low-inclination orbit with a Saturn I, or it can be placed in low polar and symchronous orbit by a Saturn $V$ and, lastly, it is dimensionally compatible with the muclear stage developme: : currently in its early stages. Therefore, such a spacecraft design would seen to have the potential for considerable longevity beyona the initial space station mission, if required.

Considerations of habitability volume reouirements, space-station size, and crew support indicate that a reasonable space-station staff of six to nine men would be desirable. The space-station designer should be nindful that the space station is an evolutionary step of the trpe that will be required for future manned earth orbital operational systens and potentialiy for manned exploration of the solar system.

Iogistics Requirenents - A dyramic experiment progran will require the flexibility of a periodic change of creupen, additional experiment equipent. and supplies, and the return of dets and samples from orbit. For practical reasons, the crev stay time should probably he 180 days or less. A typical logistics system payload might consist of approximately 6000 pounds of crew support expendables, reaction control propellant and spares, and an additional 3000 to 4000 pounds of experiments and experiment support equipment. The ability to add major experiments in the form of couplete experiment modules to the space station is highly desirable. It is unvise to attempt. to place all experiments on board at launch because some experiments could not be started until months or years after they were placed in orbit and the equipment would therefore rave been stored in space :or long periods and might eren become obsolete.

\section{COKCLUDTIG REMRKS}

The function of NASA in fulfilling the objectives of the Space Act of 1958 are the exploration of space, the advarcement of science, and the provision of services to the nation. The greater share of KASA effort to date has $t=e n$ expended in support of space explcration and saience, but as the technological and operational catsibility increase, the service function will come into full prominence through the exploitation of space for human and national benefit.

Gerdrier and Hook 
The role of NASA in meeting the space-utilization needs involves developing the technical capability, proving the applicability, and furnishing the space operations necessary to support the ultimate users of space. Earth orbital activities comprise most of the space flight missions and they primarily involve the development of technology and space operations capability, including the effective utilization of man, to satisfy the exploration, science, and service functions. In addition, most of the space flight service activity, earth resources survey, and the science activity will be perf rmed in earth orbit. The role of a space station in the carth orbital program is that of a manned orbitel research facility witish can provide accelerated development of space systems that will contrihute to the soluticn of basic national problens, proride an unequaled oprortunity for the study of crucial scientific questions, and provide the required fscility for develnping technology and procedures for proper utilization of man in space systens and as a future explorer of the planets. Sane of the significant general features which such a space station mist include are the fol:oring: a station moiule sized so as to serve the basic neeajs of the progran; a staff of six to nine men supported by flexible laboratory facilities; and a versatile logistics support system to provide for dymic prograns in each erea. 